1992

\title{
Worker Participation in Health and Safety Regulation: Lessons from Sweden
}

Eric Tucker

Osgoode Hall Law School of York University, etucker@osgoode.yorku.ca

Source Publication:

Studies in Political Economy. Number 37 (1992), p. 95-127.

Follow this and additional works at: https://digitalcommons.osgoode.yorku.ca/scholarly_works cc) (1) $(9)$

This work is licensed under a Creative Commons Attribution-Noncommercial-No Derivative Works 4.0 License.

\section{Recommended Citation}

Tucker, Eric. "Worker Participation in Health and Safety Regulation: Lessons from Sweden." Studies in Political Economy 37 (1992): 95-127.

This Article is brought to you for free and open access by the Faculty Scholarship at Osgoode Digital Commons. It has been accepted for inclusion in Articles \& Book Chapters by an authorized administrator of Osgoode Digital Commons. 


\section{Worker \\ Participation in Health and Safety Regulation: Lessons from Sweden}

\section{ERIC TUCKER}

Tntroduction The toll capitalist production takes on the lives and health of workers has been, and continues to be one of its least acceptable features. For this reason, the labour movement and political parties seeking labour's support have often made reform of occupational health and safety regulation a major objective. In recent years, for example, the New Democratic Party in Ontario has vociferously criticized the failures of the governments of the day to protect adequately the workers in the province. ${ }^{1}$ Their recent electoral success provides a great opportunity to improve the work environment and to strengthen the ability of the labour movement to influence decision making in this regard at both the provincial and enterprise levels.

One of the more recent strategies in health and safety regulation has been an enhanced role for direct worker participation, especially at the work place level. Since the 1970s, workers in Ontario, and most other Canadian jurisdictions, have been given a variety of statutory rights including the right to know the hazards present in the work place, the right to be consulted on health and safety matters by management and the right to refuse unsafe work. ${ }^{2}$ Collectively, these rights are said to comprise an "internal responsibility system" (IRS), through which compliance 
with legal standards, and improvement of the level of health and safety in the work place are to be achieved. ${ }^{3}$ Indeed, these statutory rights distinguish this IRS from market regulation and give it a legitimacy which earlier self-compliance approaches to enforcement lacked. More recently, the now defeated Liberal government enacted Bill 208, the first major legislative reform of the new regulatory regime created by the Occuptational Health and Safety Act (OHSA) in 1978.4 It was clear from the major provisions of this bill that the government hoped to shift a greater degree of regulatory responsibility onto labour and capital by creating new, and strengthening old, bipartitite structures. Not only were workers and employers to jointly achieve compliance at the local level; now they were to begin delivering other health and safety services at the provincial level, beginning with education and training. 5

The attitude of the labour movement towards this approach has been ambiguous and far from uniform. On the one hand, it has been extremely critical of the particular version of the IRS contained in OHSA and implemented by the Ministry of Labour. On the other hand, it is attracted by the Scandinavian model. Divisions within the labour movement over Bill 208 reflected different views over the appropriate role of and structures for worker participation, and are likely to raise difficulties in plotting a strategy for future reform under an NDP government. It would be useful, therefore, to critically examine the Swedish approach to occupational health and safety regulation to see what lessons might be learned from their experience. In particular, this paper explores the conditions of participation in two ways. First, under what conditions are opportunities for worker participation in health and safety regulation created and second, under what conditions is participation effective.

The methodology of the study builds on recent work in political economy which has rejected the view that social developments are the outcome of the logic of the mode of production and its internal contradictions. Instead, there has been a movement to bring workers, states, institutions, ideologies and other elements of the social formation "back in" to the analysis. ${ }^{6}$ In order to investigate the complex inter- 
actions between these elements in a social formation or in one of its subsystems, the concept of a "regime" has been employed. ${ }^{7}$ The concept itself, however, does little other than to suggest the presence of certain stabilizing regularities as well as potentially de-stabilizing conflicts. More specification is required.

The power resource model developed by Korpi and others provides a valuable starting point for identifying and analyzing the forces and relations operating within a regime of regulation. ${ }^{8}$ It focuses on the relative strength of the working class, measured primarily by the strength of unions and social democratic parties, to explain differences in the development of welfare states. There is a need, however, to specify both the conditions for power mobilization and the direction of its deployment, and to apply this analysis to the development of power resources by employers so that the focus on the relative strength of class forces is not lost. 9 Moreover, it is necessary to examine the institutional forms and characteristics of the state's various subsystems, including the law and administration. Although regime institutionalization, especially in regard to the functions assumed by the state and the development of its administrative capacities, is profoundly influenced by the historical development of power resources, its legacy affects their future. The establishment of strong welfare state regimes that constrain the market and embrace a commitment to direct worker participation in the administration of public programs and private enterprises enhances the opportunities for the development of future power resources and provides more strategic space for their deployment.

This framework is particularly well-suited to an analysis of worker participation in industry generally. It overcomes the deficiencies of conventional industrial relations studies of worker participation, often rooted in a pluralist paradigm, which focus on the minutiae of organizational structure without ever acknowledging, or coming to grips with class power and conflict. ${ }^{10}$ Moreover, because class power and its mobilization are located in a complex web of social, economic, political and institutional relations, it becomes easier to both identify and explain the contradictory forces 
and possibilities which produce and are produced by participatory structures. Finally, by analyzing the conditions of participation in this way, we can more easily assess the likelihood of the Swedish model being adopted and successfully implemented in Ontario.

Constructing the Conditions of Participation in Sweden Like Canada, Sweden developed a liberal model of health and safety regulation in the nineteenth century but, unlike Canada, it began to elaborate a social democratic alternative in the first decades of the twentieth. The central institution of health and safety regulation in the early period was the market, although customary practices continued to play a minor role in establishing the rights and duties of the parties. ${ }^{11}$ For workers, participation in regulatory decision making was to occur through bargaining, but for most this meant accepting terms unilaterally dictated by their employers. In response, craft workers formed trade unions to protect their status and bolster their power. Typically, they attempted to "bargain" by agreeing amongst themselves that they would only work at certain rates and only with members of their union. If conditions were favourable, employers who refused to accept these conditions would be boycotted. This strategy met with some success some of the time for a relatively small group of workers. Any weakness in craft organization or changes in technology or labour market conditions, however, threatened to undercut the power resources upon which this strategy depended. ${ }^{12}$ Dissatisfaction with market regulation led workers to seek protective legislation. The first steps in this direction were taken in the 1880s at a time when labour militancy was growing and political activity increasing, despite restrictions on the franchise. 13 As in other countries, early concern was directed primarily at child labour. Pre-industrial laws curbing the abuse of child labour remained in force through the nineteenth century, but were totally ineffective. In 1881 a Royal Ordinance was enacted to protect minors. Fierce resistance by employers, however, led the government to delay declaring the law in force several times and then to weaken its provisions by amendment. Moreover, enforcement responsibility 
was conferred on local health committees and municipal councils which lacked the authority to fulfill their mandate. In 1889, two years after the great mobilizing election of 1887 around the tariff, the Occupational Hazards Act was enacted, to protect industrial workers. ${ }^{14}$

This legislation imposed a general duty on employers to maintain safe and healthy work conditions. As well, some more specific obligations were set out and these were to be enforced by state-appointed inspectors. The shift in the locus of regulatory decision making from the market to the political-administrative system, however, was only partial. In effect, by delegating discretionary authority to enforcement officials, a disjuncture was created between the more publicly accessible political system and the effective centre of decision making, the inspectors. Here a number of factors weighed against workers who sought to have the legislation vigourously enforced. Only three inspectors were initially appointed to enforce the law. This was a woefully inadequate allocation of resources which significantly limited the possible success of any enforcement strategy. As well, employers had better access to the inspectors and were in a position to retaliate against employees who complained to the inspectors. Although continued political action succeeded in obtaining minor amendments to the legislation and the appointment of more inspectors, the laws remained ineffective. As a result, contract negotiation, whether individual or collective, continued to be an important, if not the primary, means of influencing employer decision making over health and safety. 15

This model of regulation was typical of most western industrializing nations during this period, including Ontario. ${ }^{16}$ It was only in the beginning of the twentieth century that the foundations for a more social-democratic regime of regulation began to be laid. A principle cause of this divergence lay in the different paths of development followed by working class organizations in various countries. These differences can be traced along four dimensions. First, Swedish unions adopted the principle of industrial, rather than craft, organization relatively early. ${ }^{17}$ Second, trade union organization was highly centralized. ${ }^{18}$ Third, the 
Swedish labour movement grew fairly steadily from the 1890 s onwards. Although it suffered a major defeat in 1909 , it recovered and grew rapidly during the 1920 s, a period during which many other labour movements suffered devastating defeats. ${ }^{19}$ Finally, the Swedish labour movement was closely intertwined with the Social Democratic Party (SAP) founded in 1889.20

As a result of these developments, the Swedish working class built a comparatively powerful labour market and political organization. Furthermore, the ideological orientation of the Swedish labour movement was becoming more socialist, even though it was decidedly reformist in its strategy. The Swedish union movement did not seek just to protect the material interests of its members; rather, it sought to promote the interests of all workers as a class. This was reflected in its early commitment to industrial unionism and to complete penetration of unionisation. Further, the SAP saw itself as the political arm of the workers' movement and believed that socialism could be achieved by obtaining universal sufferage and then legislating an end to capitalist exploitation and inequality. 21

The greater power resources of the Swedish labour movement and their more socialist ideological orientation did not stop the transformation of capitalist production in the early decades of the twentieth century. Indeed, one of the effects of the centralized character of the trade union movement, together with highly concentrated ownership in the Swedish economy, was to give impetus to cooperation amongst employers who, from the 1890 s onwards, formed federations, culminating with the creation in 1902 of SAF, a national employers' organization designed to deal with unions. Given the organizational resources of the labour movement, SAF adopted a strategy which accepted unions as a fact of life, and instead fought to secure certain principles which all of its members would adhere to whenever concluding a collective agreement. In particular, SAF fought to gain and maintain managerial control over production in their enterprises, including the preservation of the open shop. This was embodied in Article 23 (later 32) of their constitution which required that all members include a 
clause in any collective bargaining agreement made with a union, "stipulating the right of the employer to engage and dismiss workers at his own discretion; to direct and allot work; and to avail himself of workers belonging to any organization whatsoever, or to none." 22

Although the Swedish labour movement initially resisted this attempt to restrict the scope of collective bargaining, in the December Compromise of 1906 it conceded management's rights to hire and fire and to organize work in exchange for union recognition. Also in that year an act was passed which provided optional conciliation services to employers and unions unable to reach agreement. ${ }^{23}$ Otherwise, the state remained fairly inactive, although decisions of the Supreme Court of Sweden in 1915, arising out of law suits brought by employers in respect of a general strike in 1909, declared that the collective agreement was a binding contract. ${ }^{24}$ It was not until 1928 , however, that a statute was enacted, over the objections of the labour movement, making collective agreements legally binding and making strikes and lockouts over their interpretation illegal. A Labour Court was set up to adjudicate such disputes, and although the legislation said nothing about managerial rights, the court held that, in the absence of express language in a collective agreement, clause 32 was implied as part of the agreement. Even after the social democrats came to power in 1932, nothing was done to alter the 1928 law or the court's interpretation of its effect. Indeed, the basic principles of the 1906 Compromise were reaffirmed in the Basic Agreement of 1938 negotiated between LO and SAF. The only legislative change was the 1936 Act which legally guaranteed a worker's right to join a trade union and required employers to negotiate with those unions. ${ }^{25}$

The process of achieving an accord between labour and capital was not a smooth one. Sweden experienced one of the highest rates of industrial conflict in any western industrial country up until the mid-1930s. ${ }^{26}$ Notably, though, the accord was reached without a high level of active state intervention, despite the electoral success of the SAP after 1932. Moreover, labour did not mount a serious challenge to managerial control. Instead, mechanisms for joint con- 
sultation were established whereby information and advice about these issues might be exchanged. A Works Council agreement was negotiated between SAF and LO in 1946 and subsequently renewed with slight alternations in 1958 and 1966.27

The reasons for limiting worker participation in this way related to the power resources of the parties and their ideological orientations. Although the SAP controlled the government, they only occasionally held an absolute majority and, therefore, could not be too aggressive in their legislative program. Moreover, the SAP's strategy emphasized consumption politics over production politics. Managerial control over production, including the power of capital to transform the labour process, was conceded in the belief that this would promote economic growth. But free enterprise was to be socially controlled to insure that an appropriate share of the benefits of economic growth would be funnelled to the working class. Central to this strategy was a strong commitment to full employment which protected workers against the dislocations resulting from economic rationalization. Thus a form of progressive Keynesianism emerged as the major strategy of the social democratic party in the 1930s and set the pattern for Sweden's social and economic development in the buoyant postwar period. ${ }^{28}$

The development of health and safety regulation in Sweden, including the role of worker participation, reflected the pattern of these compromises. Workers experienced difficulty participating in the regulatory process created by the first health and safety legislation. In particular, they had difficulty effectively communicating with the inspectors who made the operative decisions about the legislation's requirements. To remedy this, workers at some locations elected representatives to present their grievances to the inspectors. Thus, the origin of the safety delegate was not to represent workers' interests to the employer, but rather to state officials. In 1912 Sweden enacted the Workers' Protection Act (WPA) which consolidated earlier legislation and tightened up many of the safety rules. As well, the WPA formally recognized the 'worker delegate' and required the inspector to consult with such delegates where 
they existed. The institution of the worker delegate did not, however, develop very rapidly at first. In 1920 there were only 300 work places in Sweden with such a delegate.

In the 1930s there was a shift in the focus of regulatory policy. Rather than emphasizing direct state regulation over health and safety at work, amendments to the WPA in 1931 and 1938 encouraged greater cooperation between companies and workers in the achievement of safer work places. One way this cooperation was to be accomplished was by changing the role of safety delegates. Their primary function was no longer to represent the interests of workers to the inspector, but rather to the employer. The 1931 amendment urged workers in industry, construction and transportation to elect one or more such safety delegates. The 1938 law stated that safety delegates 'should' be elected and expanded the areas in which the institution was to be encouraged, including forestry and coke oven operations. As a result of these legislative urgings the numbers of delegates grew considerably so that by 1935 there were 2,000 and by 1940 the number had doubled.

The 1938 law also suggested that joint safety committees should be formed in larger work places in order to promote health and safety at work. Such committees had already been created in a number of companies prior to the legislation, but the law encouraged their diffusion. By 1940 there were approximately 300 joint safety committees in existence.

The Basic Agreement of 1938 encouraged greater consultation between labour and capital generally, and laid the foundation for the development of further central agreements between the parties on more specific issues. In 1942 LO and SAF reached a central agreement on labour protection issues. This agreement included rules for local safety organizations, including the election of safety delegates and the establishment of joint safety committees in work places of certain sizes. A bipartite agency, the Joint Industrial Safety Council (ASN) was established by the parties to assist in the development of local safety work and the promotion of occupational health and safety more generally. 
In 1949 a revised WPA was enacted. The Act created the National Board of Occupational Safety and Health (ASS), a tripartite authority with responsibility for implementing the Act. The Act required, rather than merely encouraged, the election of safety delegates in work places with five or more employees and the establishment of joint safety committees in work places with fifty or more employees. Furthermore, it provided that a trade union could, with the approval of ASS, appoint safety delegates from outside the group of employees in a place of work. This supported the development of regional safety delegates to represent workers in small work places. Safety delegates were not to be hindered in the conduct of their duties and they were to be protected against retaliatory actions by the employer.

The organization of local safety work and the role of workers was spelled out more fully in a regulation issued by the government and in revisions to the basic agreement between LO and SAF in 1951. The most important points were that the employer and the union were obliged to educate safety delegates so that they could properly perform their duties. Delegates were directed to inform themselves of the conditions in their areas, to promote health and safety at work and to enlist the cooperation of other employees for this purpose. If a delegate considered that a particular safety measure should be taken, he or she was directed to make a proposal to the employer who in turn was required to reply without delay. If the delegate's proposal was not considered within a reasonable time the delegate was authorized to request the inspector's intervention. The delegate was authorized to submit requests directly to a safety committee where one existed and was also given the right to obtain information including any instructions issued by the inspector and the results of any tests conducted in the work place. The agreement further provided that delegates have access to accident and sick leave statistics. The inspectors were required to contact safety delegates when carrying out inspections and, by agreement, the delegate was given the right to be present during the inspection and to be paid by the employer for the time so spent. 
It is clear that worker participation at the local level was based on a consultative model. No actual decision-making authority was given to either the safety delegate or the joint committee. The legal right of employers to manage their enterprises and to control production remained unchallenged, provided of course that the employer did not violate standards of conduct established by the state. The superior position of the employer in this regard was acknowledged and affirmed in the legislation. Section 39 stated:

With a view to achieving safe and healthy working conditions in the place of employment, the employer and persons employed by him shall collaborate under the direction of the employer in maintaining a suitably organized safety service (my emphasis).

The legal and contractual arrangements made during this period remained in place until the 1970s. During this period the number of safety delegates increased slowly but steadily, as did the number of safety committees and regional delegates, notwithstanding that the number of work places actually decreased, probably as a result of increased concentration in ownership and the decline of smaller firms. ${ }^{29}$

In sum, the pattern of social democratic regulation that emerged in Sweden during this period was premised on party and trade union strength in the political arena and in the labour market. This power was exercised to advance elementary working class interests in worker protection, employment security, and social security. Moreover, worker participation in the administration of state programs and an active union presence on the shopfloor was firmly institutionalized, thereby providing both a foundation and an orientation for the future development of power resources. Private ownership and control of the means of production, however, was not seriously challenged at this time and employers were free to rationalize their production processes, subject only to consultative procedures and, in the area of occupational health and safety, minimum standards legislation. This left employer power resources substantially in tact. 
Participation and the Challenge to Fordism in Sweden A new wave of occupational health and safety reform began in the late 1960s and its directions and implications are not yet fully settled. Essentially, this wave of regulation can be seen as one which arose out of and addressed the difficulties which had been developing within the structures of accumulation and legitimation established previously. One point of pressure resulted from changes in the international economy which challenged the competitiveness of Sweden's traditional export industries. Economic rationalization entailed job loss and drives to increase productivity. Moreover, younger workers, perhaps because of the economic security they had enjoyed during their lives, were less willing to accept some of the conditions which had been present before this new wave of rationalization. Because of the government's commitment to full employment policies, rank and file concerns came to be focused on work place issues and gave rise to new demands of a qualitative character. ${ }^{30}$ Workers were refusing to accept exclusive managerial authority over the labour process and were demanding that they be given a right to participate in decisions affecting production organization. The most dramatic manifestation of labour discontent was the wave of wildcat strikes which began in December 1969 when 5,000 miners in the state-owned mines in Northern Sweden walked off the job, their principle demand being the abolition of piece rates in favour of fixed monthly salaries. These unofficial strikes spread to major manufacturing firms in central Sweden. Worker discontent also manifested itself in individual actions reflected in high rates of turnover and absenteeism. In brief, dissatisfaction rooted in the employerled rationalization of the labour process raised the priority of the politics of production over the politics of consumption, and concerns over the work environment were in the forefront of this new orientation. 31

Employers responded to these concerns by initiating experiments in work organization designed to increase job satisfaction, ${ }^{32}$ while workers emphasized the need to deal with the causes of the problem. Without repudiating the need for economic efficiency as the premise of a healthy eco- 
nomy, workers demanded to be given a voice in decision making. This would ensure that their needs and concerns were taken into account. Moreover, researchers in Scandinavia provided an important scientific foundation for the argument that improvements in the work environment required democratization of work organization. ${ }^{33}$ The upshot was that workers pressured the SAP to embark on a program of legislative reform designed to give workers greater rights to participate in and to challenge managerial decisions.

The first wave of reform legislation was aimed at strengthening industrial democracy through the development of co-determination, collective bargaining and shopfloor participation, including health and safety. With regard to co-determination, legislation was enacted in 1972 providing for two union representatives on boards of directors employing 100 or more employees. Later this was extended to companies employing 25 or more workers. In the area of collective bargaining, the Co-Determination Act (1976) incorporated the previous collective bargaining legislation of 1920, 1928 and 1936, but struck a blow at clause 32 which had limited bargaining over areas of managerial prerogative in regard to work organization. In effect, the legislation created a new framework for the negotiation of co-determination agreements between the labour market parties. Finally, in the area of shopfloor participation, union stewards were given greater rights and protections including rights to information, time and training for union work at the employers expense and protection against discrimination and retaliation. ${ }^{34}$

In the area of health and safety, legislation was enacted in 1973 and then again in 1977. Its broader scope was signalled in its title, The Work Environment Act. Health and safety regulation was to include not only the physical, but also the psychological well-being of the worker. Moreover, it enshrined the concept that worker control is a critical aspect of a healthy work environment. "Working conditions must be adapted to human physical and mental aptitudes. The aim must be for work to be arranged in such a way that the employee himself can influence his work situation." To strengthen worker influence in local health and safety 
work, the position of safety steward was strengthened. Safety delegates were given the right to halt any dangerous process pending an investigation by the inspector. They were also given the right to participate in the planning of new premises, devices, work processes, working methods and the use of substances liable to cause ill health or accidents, while employers were required to inform delegates of any changes having significant bearing on conditions in the areas they represented. Employers were also required to respond to representations made by safety delegates without delay and, failing a satisfactory resolution, the matter could either be referred to the inspector or to the joint employeremployee safety committee, where there was one. ${ }^{35}$ Under the legislation, joint committees were required in work places with 50 or more employees or where employees demanded one. Committees were required to plan and supervise local health and safety work.

Following the enactment of the legislation, a new Working Environment Agreement was negotiated between SAF, LO and PTK in 1976. ${ }^{36}$ The agreement provided more detailed rules and guidelines for the implementation of the law, the most important being that: 1) workers were given a majority of one on the joint committee; 2) at least one employer member on the committee had to hold a managerial position in the firm; 3) the committee was defined as a decision-making and advisory body; 4) the committee was given authority over company health services including the appointment of company doctors and safety engineers; and 5) unanimous decisions of the committee on budgetary matters were made binding on the company, but if unanimity could not be reached, any member could refer the matter to the inspector. 37

While this wave of legislation was being enacted, LO began exploring ways of promoting economic democracy. A committee chaired by Rudolph Meidner developed the Wage Earner Funds concept which would require employers to issue new stock in relation to their profits which would be owned collectively by employees. Over time, this would eventually give employees majority ownership in private corporations. LO endorsed the proposal in 1976. Although 
the proposal was designed to respond to a number of concerns, including the need to secure wage restraint in the face of high corporate profits, in its initial form the Wage Earner Fund proposal was directly linked to a broader program of social transformation. ${ }^{38}$

In sum, the creation of stronger institutional structures for worker participation in health and safety occurred during a period of radicalization in Sweden. The promotion of industrial and economic democracy included the idea that workers should exercise greater control over the work environment. Indeed, concerns about the work environment and the linkage between the organization of work and human health played a radicalizing role within the Swedish labour movement.

The translation of these concerns into new institutional forms for participation did not, however, determine the way these forms would be used. ${ }^{39}$ Although new institutional conditions of participation were legislated and negotiated, other conditions continued to vary, including changes in the relative power resources and ideological orientations of labour and capital. First of all, the defeat of the SAP in the elections of 1976 and 1979 had serious consequences. Not only did it diminish workers' political power, it also undermined their labour market power since employers no longer had to negotiate under the threat of legislative intervention. Second, the LO lost some of its influence over the SAP, resulting in a strengthening of forces favouring the "logic of electoral competition." This entailed the pursuit of cross-class electoral support and the de-radicalization of SAP's program. Third, Sweden was not immune from the extended international recession of the early seventies and the continuing squeeze this put on the profits of an export-oriented economy. Moreover, the increasing concentration and internationalization of Swedish capital strengthened its ability to impose its economic and ideological agenda. These pressures have influenced the SAP's policies since its return to power in 1982. It has not brought forward any new proposals to advance industrial or economic democracy. The watered down version of the Wage Earner Fund proposal enacted in 1983 eliminated any 
linkage between it and the achievement of greater worker control over corporate decision making. Overall, the emphasis of the government has been to promote the private sector as the engine of economic growth. 40

The extent to which these changes in the larger political, economic and ideological climate affected worker participation in health and safety is difficult to gauge. Certainly, the number of work sites with safety delegates and safety committees has grown steadily from 38,322 and 8,174 in 1976 to 68,883 and 26,210 in 1986.41 Currently, there are approximately 110,000 trained worker safety delegates. 42 These figures suggest that these institutions are expanding and that workers are obtaining the technical capacity to participate. They do not, of course, indicate whether workers are using these structures of participation to enhance their power and to exert greater control over their work environment. However, some indirect indicators can be examined.

The number of reported work refusals has been decreasing from 167 in 1978 to 70 in 1984.43 This statistic, however, is not a very powerful indicator of worker participation as it is open to radically different, but equally plausible interpretations. It could be viewed as an indicator of declining worker militance or as a sign that employers are more responsive to worker demands and that as a result, fewer work refusals reach the stage of being reported to the inspector.

A second possible indicator is changes in the rate of occupational injuries. These increased from an annual average of 22.8 injuries per million person-hours over the period 1970 to 1977 to 26 over the period 1977 to 1983.44 Again. however, increasing injury rates do not indicate that worker participation has become less effective. Given the way statistics are gathered, increases in injury rates may indicate greater employee awareness of the relation between work and health resulting in more accurate reporting and correspondingly higher recorded rates of occupational injury. LO surveys conducted in 1970 and 1980 show that such an increase has indeed occurred. ${ }^{45}$

These surveys also revealed that safety representatives were encountering significant difficulties in obtaining satis- 
factory solutions to the problems they raised. Only half of the problems raised by safety delegates had been investigated by the employer, and only one-quarter of the complaints resulted in countermeasures being taken. When measures were taken, the perception of their effectiveness varied depending on the nature of the problem. As well, union members who reported concerns to their safety delegates or to management did not think that the measures taken had been satisfactory. A more recent study concluded that the reforms of the 1970s have not improved health and safety in Swedish industry. Health and safety committees were found to be active, but were exercising little influence on production decisions. ${ }^{46}$

A commonly expressed view of trade unionists, government officials and employer representatives was that safety delegates and committees did not have the authority or the power necessary to assume the responsibility for the safety of the work environment, even though some employers had attempted to shift this burden on to them. It was argued that in many cases employers used these structures to hive off the safety organization from the production organization, thereby marginalizing it and making it less effective. Therefore, much discussion has focused on ways of integrating health and safety concerns into the highest levels of the firm's decision-making processes. The extent to which worker participation was to accompany this integration was less clear. Representatives from LO wanted to create a safety organization with worker representatives which would parallel the production organization so that worker representatives would be consulted at all stages. They recognized, however, that employers were resisting worker participation at the higher levels of corporate decision making. SAF indeed appears to be opposed to more worker involvement, and instead sees safety committees as essentially advisory bodies, there to prod the employer to take appropriate action. Similarly, the Labour Inspectorate's current strategy is directed at building safety into the production organization; they do not see safety committees and worker participation as the primary means of achieving this objective. ${ }^{47}$ 
Trade union officials were also aware of other problems. First, the worker majority on committees was composed of delegates from all the unions represented in the work place. In a large firm, this could consist of production workers, clerical workers, professional and technical workers and front-line supervisors. As a result, there was often a divergence of interests which had to be resolved and, in some cases, the worker representatives were likely to see health and safety from the employers' perspective. A second concern expressed by some was that committee members and safety delegates often tended to become complacent and isolated from the membership. A variety of explanations were offered for this phenomenon. The crudest one was that workers were "bought off" by being given better positions or more favourable conditions. Others were that health and safety representatives were overwhelmed by technical arguments and, therefore, tended to defer to those with more 'expertise'; that, they were not always sufficiently linked to the local union; and that, like most people, they tended to avoid conflict and as a result were satisfied if there was a dialogue with the employer. Finally, there seemed to be a general consensus that delegates and committees were more effective in dealing with the small immediate hazards that arose in the work place than with more serious systemic ones which required costly investment or substantial changes in work practices and organization. 48

In sum, it seems that the development of worker participation in health and safety at the local level has stalled in much the same way as has the movement for industrial and economic democracy. Institutional opportunities for participation have been created and used, but in the current climate it is unlikely that the legal right of workers to participate in planning as it affects health and safety will become effective until workers are able to gain greater influence in corporate decision making more generally. So far, the experience with co-determination agreements has been disappointing and it seems that workers have lost the initiative. The Agreement on Efficiency and Participation negotiated by LO, PTK and SAF promises workers more employment security and job satisfaction in exchange for 
increased efficiency and productivity, but does little to provide workers with more effective control. 49 New initiatives to improve the work environment no longer emphasize worker control but are turning to other regulatory instruments. For instance, it has recently been suggested that employers should be given economic incentives to improve safety conditions through the imposition of a payroll levy which would reflect the sickness and disability levels of the firm. ${ }^{50}$

Lessons for Ontario Recent work in comparative political economy has emphasized the need to take seriously salient differences between social formations when assessing the possibility of using similar strategic responses to common pressures they face. $51 \mathrm{~A}$ thorough comparison between the development of occupational health and safety regulation in Sweden and Ontario is beyond the scope of this paper, but we can highlight a few of the significant differences.

As indicated earlier, prior to 1900 , the regulatory responses of Sweden and Ontario were substantially similar. Both jurisdictions relied on weakly enforced minimum-standards legislation which provided workers with few opportunities to participate directly, other than through bargaining. Significant differences did not begin to develop until the first decades of the twentieth century when, as a result of their greater success in building economic and political power resources and their more socialist ideological orientation, Swedish workers legally institutionalized their right to participate by way of consultation through worker health and safety delegates and joint committees. By way of contrast, workers in Ontario suffered major setbacks in the 1920s and were unable to make any significant legislative gains in health and safety regulation until the 1970s. During the interwar years, worker participation schemes were primarily a management initiative designed as a substitute for independent trade union representation. One of the architects of this approach was Mackenzie King who recommended the creation of employee representation plans to facilitate cordial relations and to promote industrial efficiency. Health and safety was one of the issues to be addressed through 
these plans. ${ }^{52}$ A second source of employee participation was through the employer-initiated "Safety First" movement which began in the steel industry. In addition to conducting educational programs and safety competitions, employers also established safety committees whose membership included workers appointed by supervisors. Lacking decisionmaking power, these committees were designed to monitor conditions on the shopfloor and to provide a conduit for communication between workers and employers. Although enthusiasm for experiments in company welfare work faded significantly after the 1920 s, the phenomenon of safety committees survived into the 1960 s, especially in large unionized work places. ${ }^{53}$ Yet, workers did not institutionalize their right to participate in health and safety, even on a consultative basis, through nationally or provincially negotiated agreements with employers, or through legislation, despite Royal Commission recommendations for such steps in 1950, 1960 and $1967 . .^{54}$

The creation of statutory rights to know, to refuse unsafe work, and to participate in Ontario and most other Canadian jurisdictions in the 1970s represents a significant break with past practice and needs to be explained. According to Walters, the passage of new health and safety legislation in Ontario can be attributed to the state's increasing interest in lowering health care costs associated with work-related illness and injury. ${ }^{55}$ This concern partially accounts for the second wave of legislation, but does not illuminate the choice of regulatory strategy. In particular, it does not reveal why governments made concessions to labour over the right to refuse and the right to be consulted. From a power resource perspective, there is no basis for arguing that Canadian workers were able to get these rights because of a relative increase in the strength of their labour market organizations. Electoral successes by social democratic parties did, however, play a role. It was under a NDP government in Saskatchewan that these rights were first legislated in Canada; 56 and they were enacted in Ontario during a period of minority government in which the NDP was more influential than usual. Yet, a fuller explanation must go beyond these immediate indicators of power. Equally impor- 
tant is a point noted earlier: the experience of death, injury and disease at work raises contradictions in a regime of accumulation in a particularly sharp form. This was certainly the case in the 1970 s, a period in which awareness of, and concerns about, the relationship between the general environment and human health were increasing. For workers faced with conditions that arguably were becoming more dangerous as a result of technological rationalization, the work environment became a focal point of their health concerns. ${ }^{57}$ Health and safety conditions became a lightning rod for more generalized worker and trade union dissatisfaction with existing managerial and state practices which provided little opportunity for participation. Moreover, government and industry were particularly vulnerable to claims made about the adverse health effects of the existing regime because of the better than average possibilities that labour could build cross-class alliances to support their demands for reform.

Finally, we must also consider what impact these changes had on employers and the state. Employers had little to fear from the creation of consultative committees which did not reduce their control over production. Moreover, they stood to gain in at least two ways. First, the creation of a more participatory internal responsibility system was likely to reduce pressure for stronger direct state regulation. Second, the participatory structures created by statute coincided with the introduction of new management techniques designed to address low worker morale and motivation. ${ }^{58}$ They could be incorporated into this larger strategy and help realize its benefits. The strongest worker right and, therefore, the one most strenuously resisted, was the right to refuse unsafe work. Clearly, employers did not stand to benefit from the right to refuse, but their potential losses were not as great as some imagined because that right was already weakly embedded in the common law and more strongly supported in arbitration decisions under collective bargaining agreements. ${ }^{59}$ For the government, the creation of a more participatory internal responsibility system would hopefully deflect some of the pressure that might otherwise be brought to bear on them to intervene more forcefully and directly 
in regulating the work environment. Primary responsibility was assigned to the labour market parties; the role of the state was to facilitate, not to enforce.

The context in which these rights were obtained also helps explain why they resemble the rights Swedish workers acquired in 1949, and not the stronger rights obtained in the 1970s. Only in Saskatchewan was there an attempt in the late 1970 s and early 1980 s to implement changes along the lines of the Scandinavian developments of the 1970s, but these efforts came to an abrupt halt after the NDP government was defeated in 1982.60 Similarly, when the former Liberal Ontario government proposed in Bill 208 to give workers something resembling a unilateral right to shut down unsafe operations, it backed down in the face of strenuous employer opposition.61 Although some collective agreements provide for this right, most do not. The general inability of Canadian workers to construct and institutionalize strong participatory rights through collective bargaining or legislation reflects the relatively weaker power resources they can bring to bear either directly on the state and on employers, or indirectly by controlling the external environment of the firm. 62

The ability of workers in Ontario to effectively use their limited participatory rights was influenced by these same conditions. ${ }^{63}$ Needless to say, numerous problems emerged. Because the joint committees lacked any decision-making power whatsoever, the ability of workers to obtain improvements to the work environment depended on their ability to convince their employers of the need for such changes. Changes which were mutually beneficial to workers and employers were likely to be implemented, but when conflicts emerged, workers depended on either their economic bargaining power or the law to exert influence. Few substantive gains were actually made through collective bargaining. If the problem involved a violation of minimum standards established by law, the inspector could, in theory, be relied upon as a resource. The inspectors, however, were instructed to facilitate the operation of the internal responsibility system in order to achieve compliance. Thus, it was 
difficult to invoke the coercive power of the law in support of worker demands. ${ }^{64}$

A second major area of difficulty was with regard to information. Frequently workers' representatives lacked adequate technical training so that they were easily intimidated by experts or were unable to identify or understand the problems they faced in the work place. More extensive right to know legislation such as WHMIS has provided a partial remedy. ${ }^{65}$ Increased worker education conducted by the labour movement, with partial state funding, has also helped reduce some of the disparity. Note, however, that there is nothing like the Work Environment Fund or the Working Life Centre which provide valuable research capabilities in Sweden. ${ }^{66}$ Knowledge is still a resource whose production, transmission and use is predominantly controlled by employers to the disadvantage of workers.

A third major problem area was that health and safety representatives were often isolated from the work force and from the union. In part, this was intentional. The early government promoters of worker participation assumed that health and safety was not an area of conflict between labour and management. Therefore, they called for a separation between collective bargaining and occupational health and safety regulation. To the extent that disagreements emerged, worker representatives were encouraged to promote a favourable view of the employer's efforts even if they were not satisfactory. ${ }^{67}$ It is, therefore, not surprising that studies have shown that health and safety representatives are poorly linked with the work force. 68

Linkage was also a problem in Sweden. This is probably inevitable, to some degree, whenever bipartite structures of this sort are put into place. It seems, however, that the tendency for worker representatives to lose their perspective has been countered more effectively in Sweden. The trade union movement there actively promotes the view that health and safety is an issue of class conflict and not merely a technical problem. ${ }^{69}$ In Ontario some health and safety activists complain that the basic training given to health and safety representatives by the OFL focuses on technical issues at the expense of political ones. In response, some 
unions provide their own programs in order to give their representatives the political outlook and skills they believe are required for effective action. There is, moreover, pressure on trade union leaders to adopt strategies and approaches which contain militant rank and file behaviour, whether it be in the area of health and safety or other aspects of labour relations. In part this stems from a legal obligation imposed on trade union officials in Ontario not to support, encourage, or threaten an unlawful strike. Aside from legal pressures, unions have also bought into institutional arrangements which structure participation and contain it within carefully defined channels. Outbreaks of shopfloor activism may not respect those limits and may embarrass the leadership which has consented to them. Moreover, discipline and unity within the labour movement are themselves power resources, but their acquisition and maintenance have often favoured bureaucratic strategies which put the leadership at odds with activists trying to build a social movement at the base. When this happens, unions may not only limit one current source of power, the ability to disrupt, but also forego the chance to build a more powerful organization in the future. ${ }^{70}$

This brings us back to the questions asked at the beginning of this paper. To what extent and under what conditions can new opportunities for worker participation be created and used to improve the work environment and strengthen the labour movement? The debate within the Ontario labour movement over Bill 208 was but one manifestation of the dilemmas it faces in developing a responsive strategy to government and employer initiatives. Under Bill 208, unions were given the opportunity to participate in the Workplace Health and Safety Agency, a bipartite institution vested with regulatory authority to establish and implement some standards and programs for health and safety education and training. The long term strategy of the Liberal government was to delegate further regulatory authority to this Agency. In return for their participation, labour obtained, initially, shared control over funds for health and safety training and a say in establishing program criteria. At the work place level, fewer workers will be excluded from the participatory rights created in the 1970 s, but little was done to strengthen 
those rights. As noted earlier, the strongest participatory right initially proposed, the right of certified worker inspectors to unilaterally shut down dangerous operations pending the arrival of the inspector, was watered down in the final draft so that now a certified worker representative needs the agreement of the certified employer representative for a shutdown to occur.

The cost of participation under these conditions, however, is potentially quite high. First, by redelegating authority over health and safety to the labour market parties, regulation may become more market-driven, an outcome which, under current conditions, favours capital because of its superior market power. Moreover, under the new framework, organized labour may be partially demobilized because: it will have consented to and participated in the bipartite process of standard setting ${ }^{71}$ and administration which was substituted for a more directly political one; it will have made its representational credibility dependent on certified expertise rather than on shopfloor support; and it may not support its own rank and file activists who criticize the joint policies that are produced. Finally, organized labour faces a loss of autonomy in the design and delivery of its own training programs since, in order to qualify for state funding, bipartite governing boards will have to be established.

New amendments to OHSA are not a high priority for the NDP government. This creates a space to reconsider the direction health and safety reform should take. Copying Swedish approaches without considering the conditions which both support and limit their effectiveness is ill-advised. The success of Swedish workers in obtaining stronger participatory rights is a function of their labour market and political organization, and the ideology which has oriented the direction in which those resources are committed. Yet, our study has also shown that only limited success has been achieved under their current health and safety regime. The participatory institutions created for health and safety have been hived off from central authority in the firm which continues to make decisions about how production is to be organized and when and where capital is to be invested. It 
seems that major progress in strengthening workers' control over their immediate environment cannot be achieved without advances in economic democracy generally. The second major lesson to be drawn is that although state power may be used to create new sites of struggle and to alter the balance between labour and capital, its actual impact depends on the ability of the people affected to use effectively the rights they have obtained. This is one of the lessons that has been learned in Sweden.

Workplace democracy cannot simply be introduced through stronger labor legislation. Legislation must be accompanied by a widespread shop-floor struggle for democracy, which will create strong and continuing pressure for further institutional change. The absence of such an interaction between shop-floor activism and legislative reform can to a great extent explain the failure of workplace democracy in Sweden.72

Even strong participatory rights, at best, create opportunities for reform; they do not determine the results which will be achieved.

In sum, the objective should be to strengthen and develop power resources at all levels with a view toward promoting a long-term process of 'encroaching control' which will ultimately challenge the hegemony of capital. ${ }^{73}$ This requires legal, organizational and ideological strategies (not necessarily in that order). Legislation giving workers the stronger legal rights that Swedish workers currently enjoy would be desireable, but it is not enough. Prosecutions of employers under the Criminal Code in appropriate cases would both strengthen the hand of workers in their immediate dealings with employers and help change the public perception of the seriousness of employer misconduct in the work place. ${ }^{74}$ There is also an urgent need to find ways of increasing worker control over the state's health and safety bureaucracy. This would help reorient its activities and counter the pressures to accomodate employer demands for flexibility. Increased worker control, however, can only occur if trade unions become committed to this goal ideologically and adopt an organizational practice consistent with its achievement. As a starting point, the labour movement should 
integrate the theme of workers' control into their conception of a safe and healthy work environment and insist that ideology and politics find a prominent place in its health and safety training.

The process of democratizing health and safety regulation will be a highly contested, drawn out struggle. Events in Sweden, where the power resources of workers are far more developed, attest to this. Therefore, it is all the more important that the possibilities for action which arise at favourable conjunctures not be squandered.

\section{Notes}

This research was funded by a grant from the Social Sciences and Humanities Research Council. I would like to thank Antoinette Hetzler, Kjell Ericson and Gunnar Wiederhelm and the rest of the faculty and staff of the Institute for the Sociology of Law, Lund University for their invaluable assistance during my stay in Sweden. I would also like to thank Ellen Baar, Judy Fudge, Harry Glasbeek, Rianne Mahon and three SPE reviewers for their comments on various drafts. An earlier version of this paper was presented to the Canadian Law and Society Association meetings, Laval University, June 1989.

1. For example, see Ontario New Democratic Party Task Force on Occupational Health and Safety, Not Yet Healthy, Not Yet Safe, by E. Martel, M.P.P. (April 1983) and Report of the Ontario New Democratic Caucus Second Task Force on Occupational Health and Safety, Still Not Healthy, Still Not Safe, by E. Martel, M.P.P. (July 1986).

2. The current Ontario legislation is the Occupational Health and Safety Act, R.S.O. 1980, c. 321 (hereinafter OHSA). For a survey of this generation of Canadian legislation, see R. Brown, "Canadian Occupational Health and Safety Legislation," Osgoode Hall Law Journal 20 (1982).

3. For favourable descriptions of the Ministry's approach, see K. Swinton, "Enforcement of Occupational Health and Safety Legislation: The Role of the Intemal Responsibility System," in K. Swan and K. Swinton (eds.), Studies in Labour Law (Toronto: Butterworths, 1983) and Ontario, Ministry of Labour, Report on the Administration of the Occupational Health and Safety Act, submitted by G.G. MacKenzie and J.I. Laskin (Toronto: Ministry of Labour, 1987).

4. Bill 208, An Act to amend the Occupational Health and Safety Act and the Workers' Compensation Act, 2d Sess., 34 Leg. Ont., 1989 (now, S.O. 1990, c. 7).

5. The approach and major provisions of Bill 208 are nicely summarized in Ontario, Ministry of Labour, Occupational Health and Safety Reform 1989 (Toronto: Ministry of Labour, 1989). 
6. For an overview, see G. Therborn, "Karl Marx Retuming[:] The Welfare State and Neo-Marxist, Corporatist and Statist Theories," International Political Science Review 71 (1986).

7. For example see A. Lipietz, Mirages and Miracles: The Crisis of Global Fordism, trans. D. Macey (London: Verso, 1987) uses the concept "regime of accumulation"; G. Esping-Andersen, "The Three Politcal Economies of the Welfare State," Canadian Review of Sociology and Anthropology 26 (1989) discusses the "welfare state regime"; and more recently, D. Kettler, J. Struthers and C. Huxley, "Unionization and Labour Regimes in Canada and the United States: Considerations for Comparative Research." Labour/Le Travail 25 (1990).

8. W. Korpi, The Working Class in Welfare Capitalism (London: RKP, 1978), pp. 32-54; W. Korpi and M. Shalev, "Strikes, Power, and Politics in the Westem Nations, 1900-1976," Political Power and Social Theory 1 (1980); and Esping-Andersen, "Three Political Economies..."

9. For example, see G. Olsen, "Labour Mobilization and the Strength of Capital: The Rise and Stall of Economic Democracy in Sweden," Studies in Political Economy 34 (1991); T. Tilton. The Political Theory of Swedish Social Democracy (Oxford: Clarendon Press, 1990); and C. Lipsig-Mumme, "Canadian and American Unions Respond to Economic Crisis," Journal of Industrial Relations 31 (1989).

10. M. Poole, Towards a New Industrial Democracy: Workers' Participation in Industry (London: RKP, 1986) uses the power resource model effectively. For a sample of conventional industrial relations approaches, see G. Bryce and P. Manga, "The Effectiveness of Health and Safety Committees," Relations industrielles 40 (1985); T. Kochan et al., The Effectiveness of Union-Management Safety and Health Committees (Kalamazoo: W.E. Upjohn Institute of Employment Research, 1977); and J. Leopold and P. Beaumont, "Joint Health and Safety Committees in the United Kingdom: Participation and Effectiveness - A Conflict?," Economic and Industrial Democracy 3 (1982). For refreshing exceptions, see C. Codrington and J. Henley, "The Industrial Relations of Injury and Death: Safety Representatives in the Construction Industry," British Journal of Industrial Relations 19 (1981); and R. Cole, "The Macropolitics of Organizational Change: A Comparative Analysis of the Spread of Small-Group Activities," in C. Sirianni (ed.), Worker Participation and the Politics of Reform (Phila.: Temple University Press, 1987).

11. On the dominance of the market model in mid-nineteenth century Swedish labour law, see R. Fahlbeck, East is East and West is West? The Swedish Model for Industrial Relations (Lund: Juridska Foreningen i Lund, 1984); and A. Adlercreutz, "The Rise and Development of the Collective Agreement," Scandinavian Studies in Law 2 (1958). On the protracted breakdown of the pre-capitalist system of labour regulation in Sweden, see F. Schmidt, The Law of Labour Relations in Sweden (Cambridge: Harvard U.P., 1962), pp. 14-17; and J. Robbins, The Government of Labor Relations in Sweden (Chapel Hill: University of North Carolina Press, 1942), pp. 28-39.

12. Adlercruetz, "The Rise and Development...," pp. 35-42. 
13. L. Lewin, Ideology and Strategy: A Century of Swedish Politics (Cambridge: Cambridge U.P., 1988), pp. 53-122.

14. Schmidt, Law of Labour..., pp. 18-9. Lewin, Ideology..., p. 50, asserted that the tariff dispute "helped bring about the breakthrough of the popular will in Swedish politics."

15. K. Liljeqvist, "One Hundred Years Old - Here Comes the Labour Inspectorate," ASS Newsletter 1/19; and Battre arbetsmiljo (SOU 1972:86), p. 110.

16. T. Ramm, "Laissez-faire and State Protection of Workers," in B. Hepple (ed.), The Making of Labour Law in Europe (London: Mansell, 1986); and E. Tucker, Administering Danger in the Workplace: The Law and Politics of Occupational Health and Safety Regulation in Ontario, 1850-1914 (Toronto: University of Toronto Press, 1990).

17. In Sweden almost three-quarters of all trade unionists were members of either industrial or mixed unions by 1908 and in 1912, LO, the central labour federation, adopted industrial unionism as its central organizing principle. See Robbins, Government of Labor..., p. 355 and Korpi, Working Class..., p. 64. In Canada, the Trades and Labour Congress, following the lead of the American Federation of Labor, was reasserting the centrality of craft organization during this period.

18. On Sweden, see L. Jorberg, "Structural Change and Economic Growth in Nineteenth-Century Sweden" in S. Kobelik (ed.), Sweden's Development from Poverty to Affluence, 1750-1970 (Minneapolis: University of Minnesota Press, 1975), Pp. 113-8; and V. Navarro, "The Determinants of Social Policy A Case Study: Regulating Health and Safety at the Workplace in Sweden," International Journal of Health Services 13 (1983), pp. 525-6. By way of contrast, the Canadian labour movement was far more decentralized and fractious, and especially vulnerable to regional conflicts.

19. Korpi, Working Class..., p. 62. For Canadian trade unions, the 19208 were disastrous.

20. Korpi, Working Class..., p. 61. By contrast, the Canadian labour movement during this period was unable to agree on a political strategy. On the reasons for differences in developing working class parties, see G. Therborn, "Why Some Classes Are More Successful than Others," New Left Review 138 (1983), pp. 49-50.

21. See Tilton, Political Theory..., pp. 15-69; Korpi, Working Class..., pp. 76-94; and Navarro, "Determinants of Social Policy...," pp. 52430. More generally, see A. Przeworski, "Social Democracy as a Historical Phenomenon," New Lefi Review 122 (1980).

22. Cited in A. Martin, "From Joint Consultation to Joint Decisionmaking: The Redistribution of Workplace Power in Sweden," in J. Fry (ed.), Industrial Democracy and Labowr Market Policy in Sweden (Oxford: Pergamon, 1979), p. 6. On the formation of SAF, see Robbins, Government of Labor..., pp. 64-73.

23. Robbins, Government of Labor..., pp. 96-8.

24. Robbins, Government of Labor..., pp. 89-91.

25. Martin, "From Joint Consultation...." pp. 7-8.

26. Korpi, Working Class..., p. 95.

27. Martin, "From Joint Consultation...," p. 8. 
28. In addition to Tilton, Political Theory...; Korpi, Working Class...; and Navarro, "Determinants..."; see J. Pontusson, "Behind and Beyond Social Democracy in Sweden," New Left Review 143 (1984); A. Martin, "The Dynamics of Change in a Keynesian Political Bconomy: The Swedish Case and its Implications," in Colin Crouch (ed.). State and Economy in Contemporary Capitalism (London: Croon Helm, 1979), pp. 94-108; and J. Stephens, The Transition from Capitalism to Socialism (Urbana: University of Illinois Press, 1979), pp. 129-40.

29. Bättre Arbetmiljo (SOU 1972:86), pp. 110-17.

30. J. Pontusson, "Radicalization and Retreat in Swedish Social Democracy," New Left Review 165 (1987), Pp. 14-17; Navarro, "Determinants...," pp. 536-47; and Martin, "From Joint Consultation...." pp. 9-12.

31. J. Kronlund, "Organising for Safety," New Scientist 14 (June 1979); E. Asard, "Employee Participation in Sweden 1971-1979: The Issue of Economic Democracy," Economic and Industrial Democracy 1 (1980); and S. Albrecht, "Preconditions for Increased Workers' Influence: Factors in the Swedish Case," Sociology of Work and Occupations 8 (1981).

32. A. Brostrom, "Co-Determination, Work Organization, and the Rights of Ownership," Stockholm, Swedish Center for Working Life, 1984, Paper No. B26; and A. Sandberg, "From Satisfaction to Democratization," Stockholm, Swedish Center for Working Life, 1982, Paper No. A15.

33. For a sample of this work, see B. Gardell, "Scandinavian Research on Stress in Working Life," International Journal of Health Services 12 (1982); "Worker Participation and Autonomy: A Multilevel Approach to Democracy at the Workplace," International Journal of Health Services 12 (1982); Work Organization and Human Nature (Stockholm: Arbetsmiljofonden, 1987); B. Gustavsen and G. Hunnius, New Patterns of Work Reform (Oslo: Universitetsforlaget. 1981); and L. Levi, Preventing Work Stress (Reading, Mass.: Addison-Wesley, 1980).

34. See H. Heclo and H. Madsen, Policy and Politics in Sweden (Philadelphia: Temple University Press, 1987), pp. 109-25; S. Edlund, "The Swedish Model for Workers' Participation in DecisionMaking at Bnterprise Level - Experience and Prospects" (mimeograph, n.d.); and Navarro, "The Determinants...," pp. 536-9.

35. This requirement is imposed in the Work Environment Ordinance issued by the government.

36. PTK is a bargaining agency for 22 unions outside $L O$ which represent salaried employees in the private sector.

37. See S. Deutsch, "Work Environment Reform and Industrial Democracy," Sociology of Work and Occupations 8 (1981) and B. Gustavsen, "Direct Workers' Participation in Work Safety and Health: Scandinavian Strategies and Experiences," in S. Bagnara et al. (eds.), Work and Health in the 1980s (Berlin: WZB, 1985).

38. H. Milner, Sweden: Social Democracy in Practice (Oxford: Oxford U.P., 1989), pp. 126-37; Lewin, Ideology and Strategy..., pp. 274301; and Pontusson, "Radicalization and Retreat...". 
39. As C. Offe, "Social Policy and the Theory of the State," in Offe, Contradictions of the Welfare State, ed. J. Keene (Cambridge: MIT Press, 1984) p. 106 argues, "the social effects ('impact') of a law or institutional service are not determined by the wording of laws and statutes ('policy output'), but instead are generated primarily as a consequence of social disputes and conflicts, for which state social policy merely establishes the location and timing of the contest, its subject matter and the 'rules of the game'."

40. Olsen, "Labour Mobilization...." and L. Svensson, "Class Struggle in a Welfare State in Crisis: From Radicalism to Neoliberalism in Sweden," in R. Edwards et al. (eds.), Unions in Crisis and Beyond (Dover: Aubum House, 1986).

41. Calculated from the Annual Reports of the ASS, 1976-86.

42. Working Environment in Sweden, (Stockholm: Arbetsmiljofonden, 1987), 18.

43. Working Environment in Sweden, 13.

44. Calculated from Occupational Injuries in Sweden 1983 (Stockholm: ASS and Arbetsmiljofonden, 1987), Table 3:4.

45. LO, "What is Happening With Regard to the Working Environment?" (Stockholm, 1982), pp. 58-64.

46. Ibid. and K. Frick, "Can Management Control Health and Safety at Work," Economic and Industrial Democracy 11 (1990).

47. From interviews with the author conducted in Sweden in spring, 1988 and Bernt Nilsson, "Internal Control," ASS Newsletter 2/91; and "This is Systems Supervision," ASS Newsletter, 4/89. Also see ASS Newsletter, 2/90.

48. P. Liukkonen, "The Efficiency of Work Environment Activities at the Local Level" (Stockholm: Statistics Sweden, 1987?).

49. C. Berggren, "Top Management and Codetermination in Swedish Companies: Greater Union Influence Results in Better Decisions," Economic and Industrial Democracy 7 (1986); and B. Hedberg, "Worker Participation in Structural Change: Acting Out the CoDetermination at Work Act in the Swedish Steel Merger," Swedish Center for Working Life, Working Paper No. C.2 (1979).

50. See Frick, "Can Management Control..."; and "Work and Health Report by the Work Environment Commission," ASS Newsletter, 3/90 for a brief summary of that document (SOU 1990:49).

51. R. Mahon, "From Fordism to ?: New Technology, Labour Markets and Unions," Economic and Industrial Democracy 8 (1987). Generally, see the papers in the "Special Issue: Comparative Political Economy," Canadian Review of Sociology and Anthropology 26/1 (1989).

52. W.L.M. King, Industry and Humanity (1918) (Toronto: University of Toronto Press, 1973); M. E. McCallum, "Corporate Welfarism in Canada, 1919-39," Canadian Historical Review 71 (1990); J. G. Fricke, "Worker Participation in Canada: Some Lessons from the Past," Relations Industrielles 43 (1988); and B. Scott, "A Place in the Sun: The Industrial Council at Massey-Harris, 1919-1929," Labour/Le Travail 1 (1976).

53. On the history of "safety first," see C. Heron, Working in Steel (Toronto: McClelland \& Stewar, 1988) pp. 103-11; and D. Brody, Steelworkers in America (New York: Harper \& Row, 1960) pp. 165-8. 
For data on health and safety committees prior to the $1970 \mathrm{~s}$, see Ontario, Report of the Royal Commission in the Matter of the Workmen's Compensation Act (1967), p. 172; "An Evaluation of Joint Health and Safety Committees in Ontario" in ACOHOS, Eighth Annual Report, Vol. 2, (Toronto: Gov't of Ontario, 1986), p. 35; D. Macleod, "Colliers, Colliery Safety and Workplace Control: The Nova Scotia Experience, 1873 to 1910," in Canadian Historical Association, Historical Papers (1983) and Ontario, Report of the Royal Commission on the Health and Safety of Workers in Mines (Toronto: Ministry of the Attorney General, 1976), p. 156.

54. See Ontario, Royal Commission Report on the Workermen's Compensation Act (1950), p. 91; Ontario, Report of the Royal Commission on Industrial Safety (n.d. 1960?) pp. 15-17; and Ontario, Report of the Royal Commission... (1967), Pp. 172-4.

55. V. Walters, "Occupational Health and Safety Legislation in Ontario: An Analysis of its Origins and Content," Canadian Review of Sociology and Anthropology 20 (1983).

56. R. Sass, "The Implications of Work Organization for Occupational Health Policy: The Case for Canada," International Journal of Health Services 19 (1989).

57. See P. Rohan, "The Trend of Work Injuries in Canada," Canadian Family Physician 24 (1978); P. Rohan and B. Brody, "Frequency and Costs of Work Accidents in North America, 1971-1980," Labour and Society 9 (1984); Walters, "Occupational Health and Safety...," p. 424; and G. B. Doern, "The Political Economy of Regulating Occupational Health: The Ham and Beaudry Reports," Canadian Public Administration 20 (1977), pp. 20-21.

58. For critical appraisals of these strategies, see J.W. Rinehart, "Appropriating Workers' Knowledge: Quality Control Circles at a General Motors Plant," Studies in Political Economy 13 (1984); D. Wells, Soft Sell: "Quality of Working Life" Programs and the Productivity Race (Ottawa: Canadian Centre for Policy Alternatives, 1986); M. Parker, Inside the Circle: A Union Guide to QWL (Boston: South End Press, 1985); and G.J. Grenier, Inhuman Relations (Phila.: Temple Univ. Press, 1988).

59. R. Brown, "The Right to Refuse Unsafe Work," University of British Columbia Law Review 17 (1983).

60. Sass, "The Implications of Work Organization...." and "The Tory Assault on Labour in Saskatchewan," Windsor Yearbook of Access to Justice 7 (1987), pp. 143-7.

61. Toronto Star 28 September 1989, D1 and Globe and Mail 24 February 1990, A12.

62. The importance of control over this "external" environment is emphasized by J. Pontusson, "The Politics of New Technology and Job Redesign: A Comparison of Volvo and British Leyland," Economic and Industrial Democracy 11 (1990).

63. See my "The Persistence of Market Regulation of Occupational Health and Safety: The Stillbirth of Voluntarism," in G. England (ed.), Essays in Labour Relations Law (Don Mills: CCH, 1986); R. Fidler, "The Occupational Health and Safety Act and the Internal Responsibility System," Osgoode Hall Law Journal 24 (1986); and V. Walters, "The Politics of Occupational Health and Safety: Inter- 
view with Workers' Health and Safety Representatives and Company Doctors," Canadian Review of Sociology and Anthropology 22 (1985).

64. For a revealing examination of the intersection between the "internal responsibility system" and Ministry of Labour officials, see Stanley Gray v. L.J. Bergie [1984] O.L.R.B. Rep. 177.

65. WHMIS stands for Workplace Hazardous Materials Information System. For an overview, see M. Grossman, The Law of Occupational Health and Safety in Ontario (Toronto: Butterworths, 1988), chap. 11.

66. In 1978, federal legislation created the Canadian Centre for Occupational Health and Safety. It is governed by a tripartite board, but is scheduled to lose its federal funding. Its major role is the dissemination of information, not its generation.

67. See, Ontario Report of the Royal Commission on the Health... (1976), p. 250; and Report of the Joint Federal-Provincial Inquiry Commission into Safety in Mines and Mining Plants in Ontario, Towards Safe Production, Vol. 1 (1981), p. 88.

68. V. Walters and T. Haines, "Workers' Use and Knowledge of the 'Internal Responsibility System': Limits to Participation in Occupational Health and Safety." Canadian Public Policy 14 (1988) and SPR Associates Inc. et al., "An Evaluation of Joint Health and Safety Committees in Ontario," in Advisory Council on Occupational Health and Occupational Safety, Eighth Annual Report Vol. 2 (1986), p. 83.

69. LO, "The Working Environment is Ultimately a Question of Class," (n.d.) and LO, "Safety Delegates - Spearheads of the Working Environment," (n.d.).

70. Generally, see F.R. Annunziato, "Gramsci's Theory of Trade Unionism," Rethinking Marxism 1 (1988); J. Kelly, Trade Unions and Socialist Politics (London: Verso, 1988); and C. Offe and H. Wiesenthal, "Two Logics of Collective Action: Theoretical Notes on Social Class and Organizational Form," Political Power and Social Theory 1 (1980), pp. 103-9.

71. For instance, in 1987 the Ontario government established the Joint Steering Committee on Hazardous Substances in the Workplace with a mandate to develop and review regulations. In large measure, this was done in response to organized labour's dissatisfaction with the preexisting designated substance regulation process. As of the spring of 1991, it appears that the joint committee has failed to reach agreement on any major substantive issue and no regulations have been promulgated. See The First Report of the Joint Steering Committee on Hazardous Substances in the Workplace (Ontario Ministry of Labour, 1990).

72. Lennart Svensson, "A Democratic Strategy for Organizational Change," International Journal of Health Services 19 (1989), pp. 319, 331. Also see Sirianni (ed.), Worker Participation..., pp. 26-7.

73. Richard Hyman, Marxism and the Sociology of Trade Unionism (London: Pluto Press, 1971), pp. 47-8.

74. H.J. Glasbeek, "A Role for Criminal Sanctions in Occupational Health and Safety," in Meredith Memorial Lectures (Montreal: Editions Y. Blais, 1989); and Law Reform Commission of Canada, Workplace Pollution, Working Paper 53 (1986). 